\title{
Princípios e modelagem da comunicação nas organizações
}

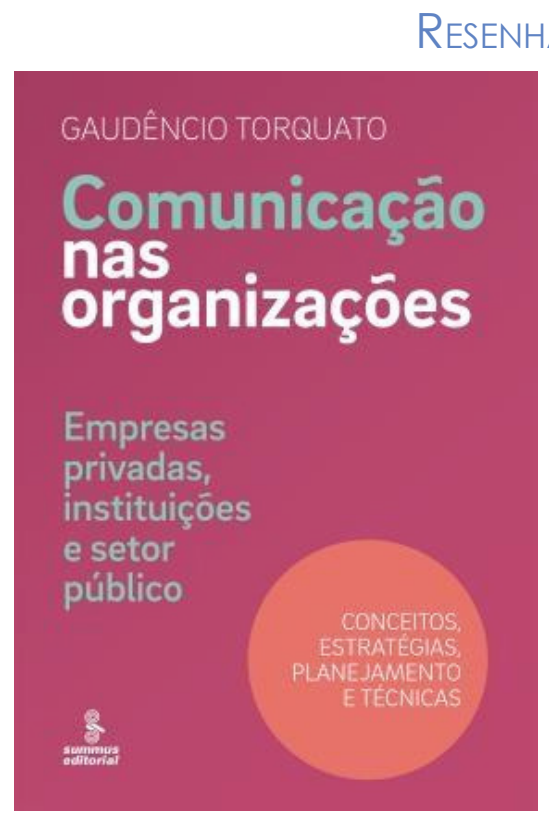

\section{Adilson Roberto Costa}

Mestrando em Comunicação pela Universidade São Caetano do Sul. Professor universitário, executivo de gestão e consultor empresarial.

E-mail: adilsonr.costa@gmail.com

Gaudêncio Torquato, jornalista, professor doutor da Universidade de São Paulo (USP) e conhecido autor brasileiro de livros e artigos sobre o tema da comunicação no ambiente organizacional, além de especialista em Marketing Político, faz nesta obra uma atualização de seu livro anterior Tratado de Comunicação Organizacional e Política (2002), trazendo algumas novas contribuições ao tema, considerando os novos cenários econômicos, sociais e tecnológicos para as empresas no Brasil. Também traz contribuições importantes para os profissionais da comunicação, traçando rumos e modelos de planejamento e técnicas operacionais para a atuação desses profissionais, tanto em empresas privadas e instituições como no poder público, cabendo destaque para um case específico de comunicação impressa no meio rural. O livro se divide em duas grandes partes: “Conceitos e Lições”, em oito capítulos e "Planejamento, Análises e Estudos Aplicados", em doze capítulos.

Na primeira parte, o autor vale-se da análise sistêmica da administração empresarial para explicar a necessidade da comunicação se tornar também um modelo sistêmico que envolva, de forma harmônica e sinérgica, um conjunto de atividades e responsabilidades, ao invés de modelos estanques e compartimentados. Como um sistema social de partes integradas e inter-relacionadas, "teremos o quadro para radiografar a empresa sob o prisma sociológico, psicológico e antropológico, bases fundamentais para a análise da questão da comunicação" (TORQUATO, 2015, p. 22). 
Gerar consentimento, por meio da comunicação expressiva-emocional, é a meta final da comunicação organizacional e o objetivo funcional dos profissionais atuantes no setor. Esse raciocínio reflete a mensagem de Torquato, que procura sempre alinhar a dinâmica da comunicação à dinâmica empresarial, tentando sistematizar o funcionamento de uma com o perfil operacional da outra. Assim, propõe uma análise sobre a eficiência e eficácia da comunicação voltada para alcance de objetivos organizacionais. Seu discurso se volta primordialmente para o profissional da comunicação e para os administradores de empresas. Se a eficiência organizacional é resultado do uso racional de recursos aplicados no processo de produção e a eficácia se traduz na capacidade organizativa em gerar valor para o mercado, a comunicação, como função-meio em apoio e direcionamento para as funções-fins, também deve se estruturar para responder às necessidades organizacionais.

Ainda na primeira parte, o autor procura formular uma metodologia de aplicação técnica do processo de comunicação organizacional com base em uma relação harmoniosa e sistêmica e oferece um panorama da evolução social histórica das organizações. Procura estabelecer uma relação instrumental da comunicação para alcance de objetivos e para interpretação da realidade social e do mercado consumidor, fatores aos quais as empresas estão sujeitas, identificando as necessidades e fazendo os ajustes da comunicação necessários aos novos cenários.

Finalizando a primeira parte, o autor aborda a comunicação organizacional enquanto atividade estratégica dos negócios, estruturada num núcleo irradiador de atos comunicativos coerentes e congruentes - tanto para as áreas de comunicação cultural como coletiva e do sistema de informação -, com visão social e política e por meio de uma coordenação geral profissional que incorpore as funções clássicas da comunicação.

Na segunda parte do livro, intitulada "Planejamento, Análises e Estudos Aplicados", Torquato faz um diagnóstico do cenário de negócios, especificando as condições macro ambientais que cercam as organizações contemporâneas, com foco no século XXI. Pela análise do professor, a internet aproxima definitivamente modelos e estratégias corporativas, tornando-as globais, impulsionando os relacionamentos interpessoais e fazendo emergir uma sociedade mais participativa e exigente, com base em modelos exteriores que impregnam toda a sociedade.

Um dos aspectos explorados pelo autor é a proposta de coerência entre a comunicação social/institucional e a mercadológica, por meio de um conteúdo uniforme e do uso de canais apropriados, num modelo sinérgico e sistêmico com as novas tecnologias de relacionamento interpessoal, intergrupal e interorganizacional.

Na última parte, chama atenção a abordagem técnica do autor sobre o planejamento de uma estrutura de comunicação jornalística voltada para o meio rural. Torquato revela, 
com detalhes, como mapear o público-alvo e a linguagem comunicativa, bem como o formato de editoração, as prioridades das matérias, a análise e a avaliação de resultados.

Para o autor, a fase de uma comunicação mercadológica artificial, voltada exclusivamente para reforçar as virtudes da empresa ou de seu produto, está em franca decadência. $\mathrm{Na}$ atualidade, a empresa deve entender sua importância como espaço de convivência e como alavanca do progresso econômico, como coagente de proteção ambiental e de gerenciamento de programas de produção sustentáveis, focada numa prática comunicativa franca e honesta, sem subterfúgios ou entrelinhas. Importa o fortalecimento de mensagens capazes de sensibilizar não somente seus consumidores, como também o poder público e a sociedade em geral.

Torquato finaliza sua obra abordando os aspectos da ética no ambiente empresarial, afirmando que considera muito importante o passo avante que as organizações deram recentemente com a figura do ombudsman. Desenvolve uma crítica construtiva do papel de Relações Públicas no contexto empresarial, especialmente quanto à necessidade de alinhamento do discurso socioinstitucional da empresa ao marketing de produto. Relembra o caso da empresa Union Carbide, cuja falha de operação contaminou e matou milhares de pessoas na Índia na década de 1980. Procura sensibilizar os dirigentes de empresas no sentido de dar transparência às suas operações e produtos através de uma comunicação realista e que incorpore a visão humanística ao dialogar com a comunidade onde está inserida.

Finalmente, o autor propõe uma metodologia para o processo comunicativo com foco em organizações públicas - que padecem de concepções organizativas ultrapassadas e de barreiras socioeconômicas quase intransponíveis - e instituições representativas da sociedade, como sindicatos e federações.

TORQUATO, G. Comunicação nas organizações: empresas privadas, instituições e setor público. São Paulo: Summus, 2015. 